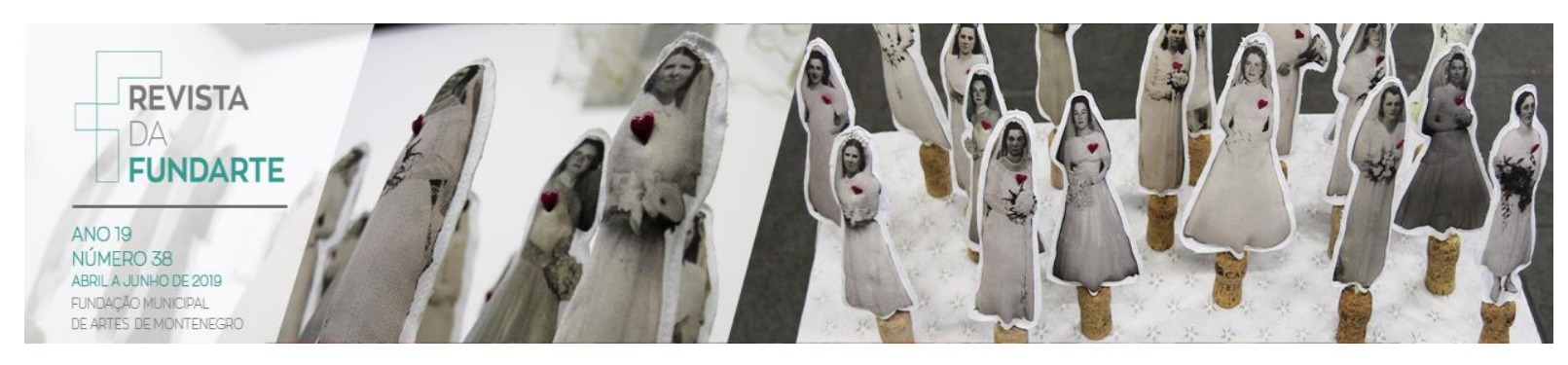

\title{
NAVEGAR O TEATRO CONTEMPORÂNEO: UMA EXPERIÊNCIA DA FRUSTRAÇÃO À AUTONOMIA
}

\author{
Fernanda Marilia Gomes da Rocha ${ }^{1}$
} Clóvis Dias Massa²

\begin{abstract}
Resumo: $O$ artigo discorre sobre pressupostos do trabalho do espectador de teatro, encarando este fazer como um ato produtivo. A partir dos avanços dos estudos da semiótica teatral ao longo do século $\mathrm{XX}$, a noção de recepção ganha relevância e os estudos sobre o espectador se mostram cada vez mais refinados. Neste sentido, o objetivo é buscar princípios fundamentais para a relação teatral na atualidade e analisar que tipo de esforços são requisitados do espectador diante do espetáculo teatral contemporâneo. Este trabalho é fruto de um estudo teórico oriundo da pesquisa de Mestrado realizada no Programa de Pós-Graduação em Artes Cênicas da UFRGS em 2012.
\end{abstract}

Palavras-chave: Espectador; Relação Teatral; Fazer teatral contemporâneo.

\section{BROWSE THE CONTEMPORARY THEATER: AN EXPERIENCE OF FRUSTRATION TO AUTONOMY}

\begin{abstract}
The article discusses the assumptions of the theater spectator's work, viewing this as a productive act. From the advances in the study of theatrical semiotics throughout the twentieth century, the notion of reception gains relevance and studies on the spectator show themselves to be more and more refined. In this sense, the objective is to seek fundamental principles for the theatrical relation in the
\end{abstract}

${ }^{1}$ Doutoranda do Programa de Pós-Graduação em Artes Cênicas da Universidade Federal do Rio Grande do Sul, sob a orientação da Profa. Dra. Vera Lúcia Bertoni dos Santos e bolsista CAPES. Mestra em Artes Cênicas (UFRGS, 2012) com pesquisa intitulada "O Hábito Habitável: a experiência de ser espectador com alunos de uma escola pública de Porto Alegre" com orientação do Prof. Dr. Clóvis Dias Massa. Graduada em Licenciatura em Teatro (UFRGS, 2007). Trabalha como atriz e pesquisadora nas áreas da Recepção Teatral e Pedagogia do Teatro. Como professora, leciona desde 2008 na rede estadual do RS e em oficinas de teatro e palhaçaria.

${ }^{2}$ Pesquisador acadêmico no campo da dramaturgia e da história do teatro, da teatralidade, da poética e da estética teatrais. Docente orientador de Mestrado e Doutorado no Programa de Pós-Graduação em Artes Cênicas da UFRGS. Coordenador do Programa de Pós-Graduação em Artes Cênicas da UFRGS, em Porto Alegre. Professor Associado do Departamento de Arte Dramática do Instituto de Artes da UFRGS, em Porto Alegre/RS, na área de História do Espetáculo, Dramaturgia e Teoria do Teatro. Doutor em Teoria da Literatura pela PUCRS, com a tese Estética Teatral e Teoria da Recepção, com Estágio Doutoral realizado na Université Paris 8 Vincennes-Saint Denis/França. Mestre pela Escola de Comunicações e Artes da USP, com a dissertação O Paradoxo de Criação do Ator na Encenação Teatral. Graduado em Artes Cênicas: Hab. em Interpretação Teatral pela UFRGS. Integrante do Grupo de Pesquisa Teoria Teatral: História, Dramaturgia e Estética do Espetáculo, vinculado ao Diretório de Grupos de Pesquisa do CNPq. Coordenador da pesquisa institucional Dramaturgia e Sociedade: Escrituras do Teatro de Hoje nas Fronteiras da Ficção, desenvolvida no Programa de Pós-Graduação em Artes Cênicas da UFRGS. Realizou pesquisa de pós-doutorado sobre o Teatro de Testemunho, entre novembro de 2017 e outubro de 2018 no Institut de Recherche en Études Théâtrales da Université Sorbonne Nouvelle Paris 3/França, sob a supervisão de Joseph Danan, dentro do Groupe de Recherche sur la Poétique de la Scène Contemporaine, coordenado por Catherine Naugrette e Joseph Danan. Coordenador do GT Dramaturgia: Tradição e Contemporaneidade, na ABRACE-Associação Brasileira de Pesquisa e Pós-Graduação em Artes Cênicas.

ROCHA, Fernanda Marilia Gomes; MASSA, Clóvis Dias. Navegar o teatro contemporâneo: uma experiência da frustração à autonomia. Revista da FUNDARTE, Montenegro, p.33-45, ano 19, ํㅡ 38, abril/junho de 2019.

Disponível em: http://.seer.fundarte.rs.gov.br/index.php/RevistadaFundarte/index> 28 de junho de 2019. 


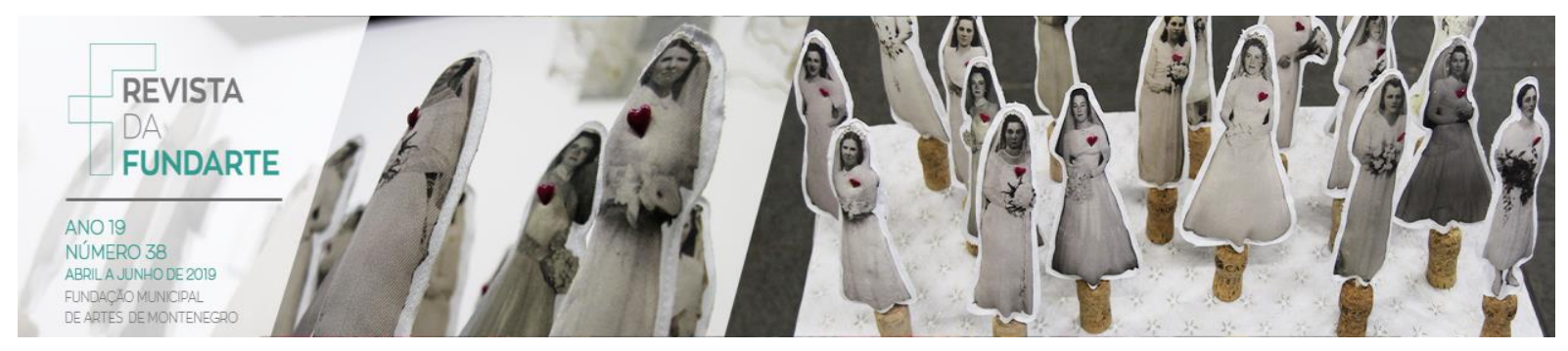

present time and to analyze what kind of efforts are required of the spectator before the contemporary theatrical spectacle. This work is the result of a theoretical study from the Master's research carried out in the Postgraduate Program in Performing Arts of UFRGS in 2012.

Keywords: Spectator; Theatrical Relationship; Contemporary Theather.

Com o objetivo de buscar princípios para a relação teatral na atualidade e analisar que tipo de esforços são requisitados do espectador diante do espetáculo teatral contemporâneo, pergunta-se: o que mudou em relação à recepção do espectador frente a este contexto cênico atual? Para buscar responder a essa questão, o estudo irá abordar, em um primeiro momento, algumas noções importantes sobre a atividade espectatorial e, ainda, analisar como a percepção e a atividade do espectador passa a se reconfigurar a partir das mudanças ocorridas na cena teatral dos últimos anos. Essa reflexão tem como origem o estudo teórico de autores como Marco De Marinis, Hans-Thyes Lehmann, Edgar Morin e Flávio Desgranges, resultante da pesquisa de Mestrado realizada no cruzamento entre as áreas da Recepção Teatral e da Pedagogia do Teatro, que possibilitaram compreender relevantes transformações do fazer teatral e de seus processos receptivos na contemporaneidade. A pesquisa realizada, de caráter qualitativo, buscou discernir princípios para a construção do gosto estético e analisar as contribuições que a experiência estética pôde trazer para os sujeitos-espectadores (estudantes do Ensino Fundamental de uma escola pública de Porto Alegre que participaram do estudo e que tiveram acesso a obras teatrais de forma continuada).

A perspectiva escolhida neste trabalho encara o fenômeno do teatro em seu caráter eminentemente relacional, ou seja, sua essência está ligada a um processo comunicativo em presença. Compreende-se a relação teatral como uma interação significante, na qual os dois polos da comunicação estão dispostos de maneira cooperativa. Como explicita Marco De Marinis:

Nesta concepção pragmática da relação teatral, o papel do espectador se revela sempre como decisivo, sendo este, em suma, o único e verdadeiro realizador das potencialidades semânticas e comunicativas da representação. (DE MARINIS, 2005, p. 107, tradução nossa).

ROCHA, Fernanda Marilia Gomes; MASSA, Clóvis Dias. Navegar o teatro contemporâneo: uma experiência da frustração à autonomia. Revista da FUNDARTE, Montenegro, p.33-45, ano 19, ํㅡ 38 , abril/junho de 2019.

Disponível em: http://.seer.fundarte.rs.gov.br/index.php/RevistadaFundarte/index> 28 de junho de 2019. 


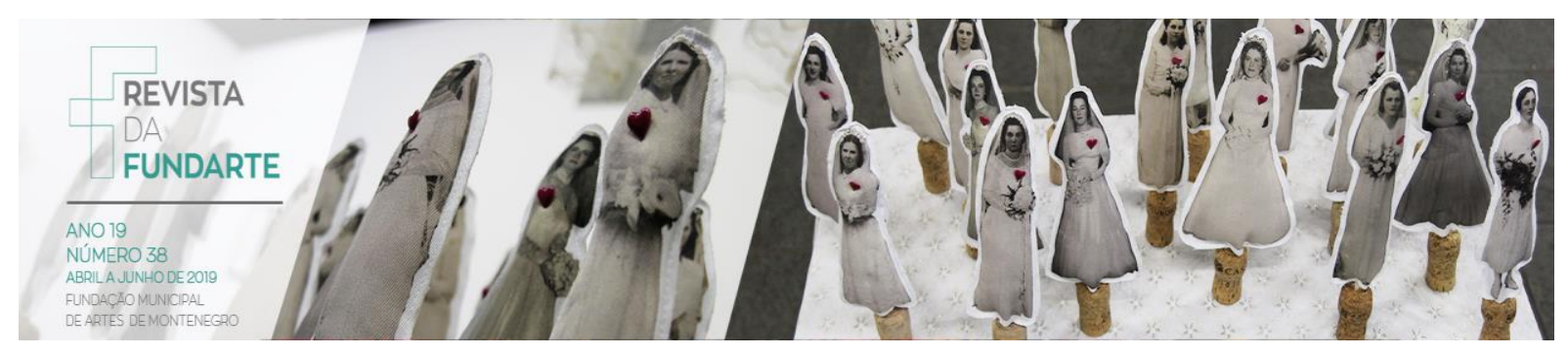

Sob esse prisma, o espectador é ativo, atuante no processo criativo de recepção da obra espetacular. No entanto, há vários fatores que influenciam ou prejudicam o processo receptivo por parte do espectador. De fato, a comunicação que se estabelece no encontro teatral não é objetiva, nem determinante. Não há critérios, nem acordos que possam garantir fidelidade às intenções expressivas dos artistas da obra. Afinal, o espectador não é meramente um espelho que possa refletir as qualidades presentes no espetáculo. Suas impressões são singulares e, portanto, parciais. No momento de contato com a cena, o receptor faz um processo individual de escolhas.

A partir dos avanços dos estudos da semiótica teatral ao longo do século $X X$, desde o momento em que ela passa a analisar o espetáculo relacionando-o ao seu contexto comunicativo, houve uma verdadeira mudança do objeto de análise. Com a relevância da noção de recepção, a relação teatral passa a ser o foco principal da semiótica, permitindo compreender o papel fundamental do espectador, pressupondo-o como cooperador na criação teatral. Entende-se hoje que o espectador constitui a obra junto aos atores, na relação que se estabelece entre ambos, no momento do encontro com o espetáculo.

No teatro, o espectador exerce uma atividade que podemos denominar como trabalho, como pontua Flávio Desgranges:

A especialização do espectador se efetiva na aquisição de conhecimentos de teatro, o prazer que ele experimenta em uma encenação intensifica-se com a apreensão da linguagem teatral. O prazer estético, portanto, solicita aprendizado. A arte do espectador é um saber que se conquista com trabalho .(DESGRANGES, 2010, p.33).

Nesta atividade de ser espectador estão imbricados aspectos ligados a um tipo de envolvimento reflexivo e passional. Ou seja, no ato de recepção, cognição e emoção atuam de maneira conjunta. De acordo com Anne Ubersfeld, mais do que qualquer outra atividade, o teatro exige um trabalho, uma inscrição complexa, 


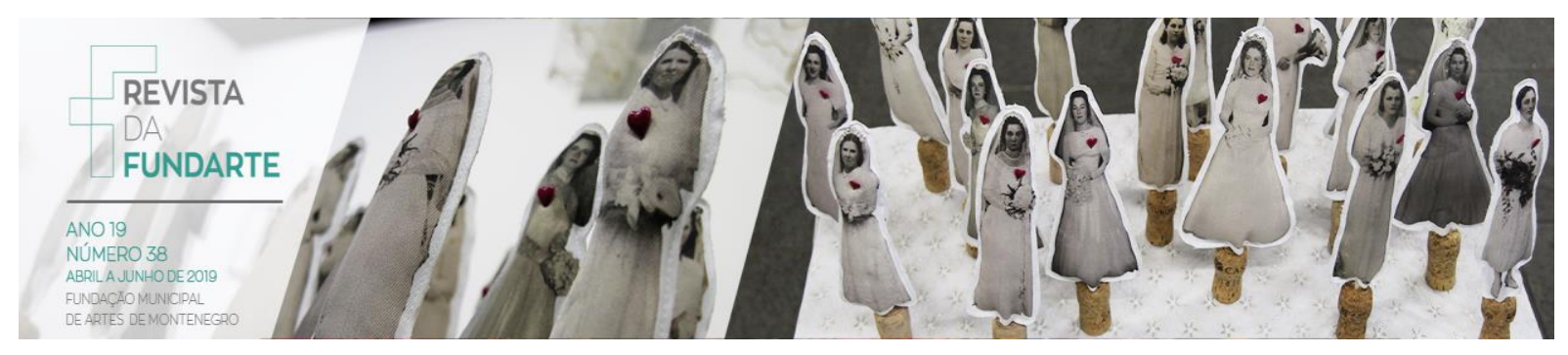

voluntária e involuntária, em um processo (UBERSFELD, 2005, p. 27). A complexidade ressaltada por ela, tem a ver com a pluralidade informacional que compõe um espetáculo teatral, no qual estão presentes signos de origens diversas que geram, por consequência, percepções múltiplas e multifacetadas. Em decorrência desse fator é que se indica um tipo de esforço que é próprio do espectador teatral. Como um espectador iniciante se prepara para este trabalho complexo? O que é exigido dele durante o processo receptivo do espetáculo? É o que se pretende discutir e elucidar mais a frente neste artigo.

O trabalho do espectador também se relaciona à busca por sentido: Para $O$ espectador jamais existe percepção sem interpretação (DE MARINIS, 2005, p. 91). A "aventura" de ser espectador está no caminho que se escolhe percorrer no momento do encontro com a cena, em uma busca que é pessoal, conforme Josette Féral:

\begin{abstract}
Anne Ubersfeld mostrou muito bem como o prazer que experimenta 0 espectador é naturalmente o de re-conhecer, mas também o de descobrir. A nós, os espectadores, não nos agrada que nos indiquem explicitamente 0 sentido que tal ação, tal gesto, tal personagem deve ter. Não nos agrada que o trabalho de análise e interpretação seja feito em nosso lugar. Nosso prazer provém, melhor, de uma certa busca, de um caminho que a cena nos permite recorrer. A cena traça suas grandes linhas, mas não faz o caminho por nós. Desenha vias e pistas em certas direções, mas nos deixa ali para aventurar-nos. Nesse trajeto que efetua o espectador em solidão que reside um dos prazeres do teatro. (FÉRAL, 2004, p. 125, tradução nossa).
\end{abstract}

O prazer está ligado, portanto, à descoberta e ao trajeto efetuado por cada espectador. De Marinis aponta que essa possibilidade própria de escolhas pode ser denominada como autonomia criativa. Parte deste trabalho, de acordo com o autor, já se encontra pré-determinado pela proposta do espetáculo teatral em si, todavia isso não torna determinante sua recepção por parte dos espectadores. Ou seja, ainda assim, o espectador permanece ativo e autônomo em suas escolhas de como interpretar ou como se relacionar com a obra. Também de acordo com ele, há precondições receptivas, ou seja, questões que condicionam a qualidade da relação com o espetáculo. Pode-se dizer que essas questões estão ligadas a fatores sociais (classe, profissão, formação escolar, sexo, idade), psicológicos, cognitivos e não-

ROCHA, Fernanda Marilia Gomes; MASSA, Clóvis Dias. Navegar o teatro contemporâneo: uma experiência da frustração à autonomia. Revista da FUNDARTE, Montenegro, p.33-45, ano 19, ํㅡ 38, abril/junho de 2019.

Disponível em: http://.seer.fundarte.rs.gov.br/index.php/RevistadaFundarte/index> 28 de junho de 2019. 


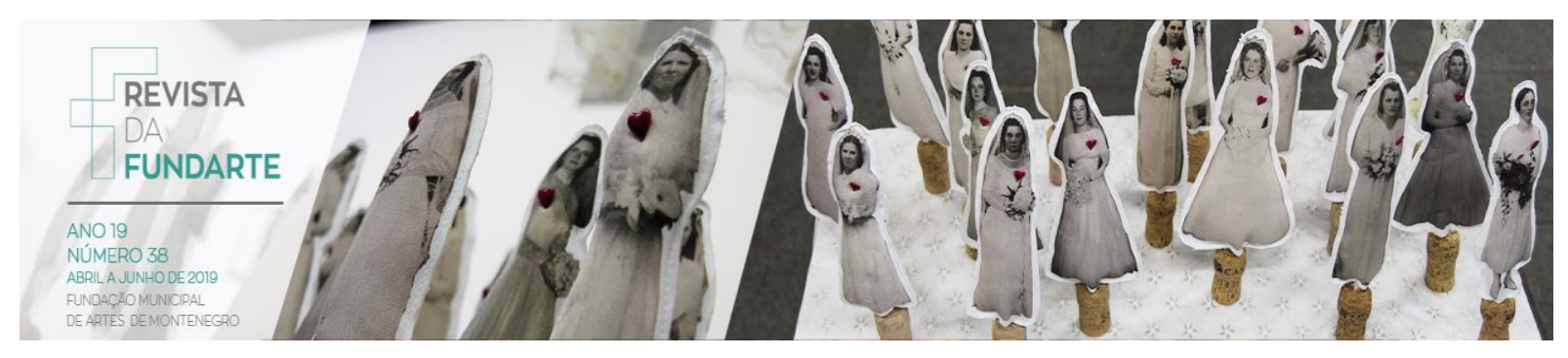

cognitivos. Também é preciso levar em conta os conhecimentos que compõem a competência teatral do espectador, ou seja, seu grau de formação acerca do teatro. Cabe ainda considerar seu conhecimento sobre a peça assistida, suas expectativas em relação à mesma e as condições concretas em que se deu a recepção do espetáculo.

Em se tratando do teatro em nossa contemporaneidade, não se pode deixar de considerar que ocorreram transformações significativas, que refletiram nos modos de criação dos espetáculos e, consequentemente, na recepção por parte dos espectadores. Neste sentido, o que mudou em relação ao trabalho do espectador frente a este contexto atual? Para refletir sobre a questão, cabe analisar quais foram as mudanças mais relevantes ocorridas, no que se refere à nossa realidade e à cena teatral dos últimos anos.

Nossa presente época, marcada pela incredulidade, a quebra de barreiras, a relatividade, e outros possíveis estigmas, situa-nos em um terreno de constantes incertezas. Contudo, os novos discursos de nosso tempo não compreendem uma visão negativamente reducionista sobre a realidade, ao contrário, revelam o homem e o universo em sua complexidade. A multiplicidade de descobertas científicas, filosóficas e outras, modificou a noção de uma "verdade absoluta", e ainda possibilitou o diálogo entre as áreas do conhecimento de forma transdisciplinar e a partir da subjetividade dos sujeitos. O ritmo das mudanças revelou o tempo e o espaço como relativos e fragmentados. A harmonia tornou-se coerente a partir do caos. Assim, novas formas de pensamento vão constituindo novos processos criativos e novas formas de ser artista. Alguns princípios do pensamento complexo, conceituados por Edgar Morin (2003), podem bem ilustrar os paradigmas do movimento contemporâneo. Primeiramente, temse a ideia da dialógica, que compreende a convivência de opostos, ou seja, a dualidade possível na unidade. A recursão organizacional compõe o pensamento cíclico, capaz de romper com a linearidade simplista de causa e efeito ou ainda processo e produto. Por fim, Morin propõe o conceito do holograma, no qual se entende a parte integrada no todo e o todo integrado na parte. 


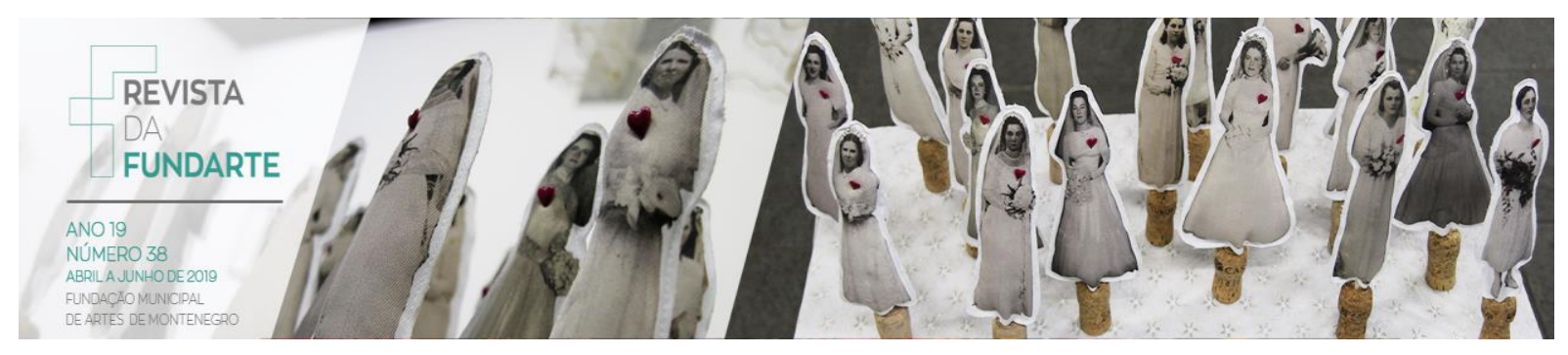

Mas de que modo essa complexidade conceituada por Morin pode ser transferida para o jogo da cena? Ou ainda, de que maneira a própria cena é capaz de revelar os princípios desse pensamento? Assim, percebe-se, por exemplo, que o princípio da dialógica pode se apresentar na cena a partir do convívio de discursos antagônicos em uma mesma obra, pela presença de referências culturais múltiplas ou, ainda, através do processo de desficcionalização, no qual são colocadas para o público um jogo de ações não-representadas. O princípio recursivo aparece, por exemplo, no jogo entre o processo e o produto, no qual ambos estão implicados e reverberam-se mutuamente. Já o princípio da holografia vê-se exposto em cena a partir da proposta na qual todos os elementos do espetáculo têm a mesma importância e cada um deles pode representar sua totalidade.

Portanto, é nesse contexto que se situa o fazer teatral atualmente e, por sua vez, não poderia estar à parte deste movimento inquietante, que tem conseguido provocar múltiplas redes de conexões. Aliás, pode-se caracterizar a teatralidade contemporânea com este verbo amplo em suas possibilidades: provocar. O teatro hoje tem, sobretudo, provocado. $\mathrm{E}$ isso abrange os propósitos de desafiar, incitar, excitar, produzir. O fazer teatral contemporâneo situa-se nesse terreno instável, de constantes mudanças e descobertas, o qual tem conseguido provocar os artistas a buscar novos recursos e modos de fazer teatro. O que, por conseguinte, acaba por provocar e desafiar os espectadores a não se acomodarem confortavelmente em suas poltronas, traçando caminhos inéditos, a cada nova ida ao teatro.

A proposta cênica atual não se liga necessariamente a um gênero, mas à possibilidade de deslocar o olhar do espectador para o que não havia sido percebido por ele, ou seja, propõe uma interrupção. Este conceito, trazido por Lehmann, é abordado nas teorias sobre o teatro pós-dramático (LEHMANN, 2007) e busca romper com a noção de teatro vinculado a uma narrativa. Nesse sentido, novas possibilidades cênicas são exploradas, em manipulações sensíveis do tempo, do espaço, do corpo, do movimento, das imagens e dos recursos tecnológicos. A lógica da cena se desvincula da "psico-lógica" de um personagem e a peça como um todo se liberta dos 


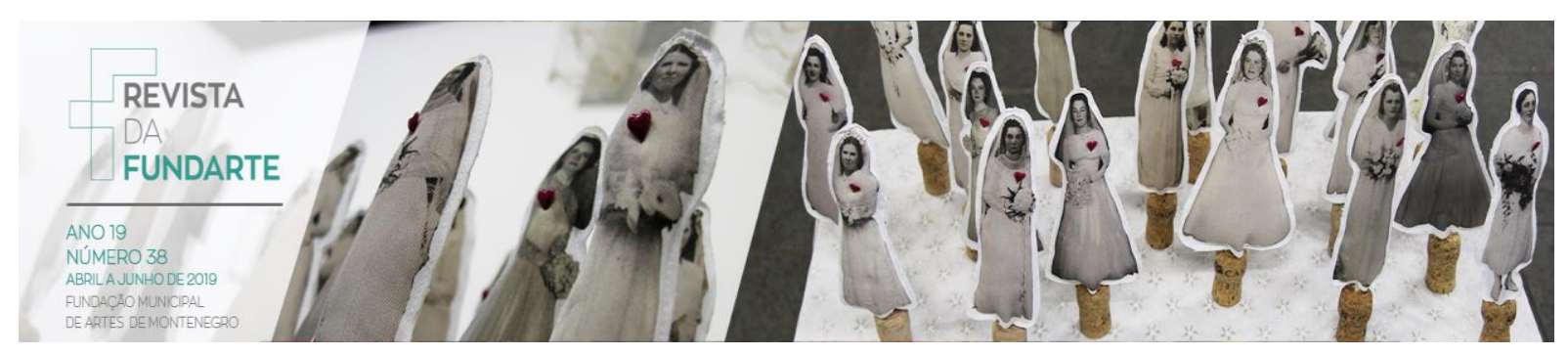

imperativos do drama. Dessa maneira, são propostos gestos de interrupção ao receptor contemporâneo, como o autor explicita a seguir:

\begin{abstract}
Esse conceito da interrupção e da cesura é muito simples, mas tem muitas significações. Ele não se relaciona somente com essa percepção do sensível, com a surpresa e com a coisa inesperada. Ele se relaciona também com os nossos conceitos e com o nosso pensamento. Pode funcionar como um choque que faz com que a realidade se torne, de repente, uma coisa não mais possível, e que nos faça pensar a respeito disso. $\mathrm{E}$ com isso eu chego ao ponto, que é o fato desse conceito do teatro pós-dramático e das várias formas de teatro pós-dramático serem respostas, de maneiras muito diferenciadas, a uma questão. E essa questão comum é: como podemos numa sociedade como a que vivemos hoje, de mídia e de massa, criar através do teatro essa situação de interrupção? (LEHMANN, 2003, p.11).
\end{abstract}

Nesta linha de proposição cênica há uma espécie de dinâmica, na qual não existem hierarquias na forma de composição dos signos teatrais (imagem - som movimento - palavra). Assim, ocorre um processo de mobilidade, do ponto de vista da criação artística e também da recepção. Este tratamento não-hierárquico dos signos, em acordo com Lehmann, visa a uma percepção sinestésica. Dessa forma, a consequência desse processo é uma mudança de atitude por parte do espectador.

Além disso, ainda pode-se levantar o processo de fragmentação colocado em cena, que expõe os mecanismos do fazer teatral e propõe uma prática e uma leitura não-linear da obra. O corpo do ator pós-dramático se coloca de forma a não mais representar, mas a apresentar-se, trazendo a realidade para o palco. $O$ uso de tecnologias também evidencia que o surgimento de novas criações artísticas proporciona novas situações perceptivas destinadas ao espectador de nossa época. $O$ uso de novas mídias, neste sentido, não vem com o objetivo de criar algum tipo de ilusão, mas para alterar a percepção do receptor. A imagem de um corpo projetado é capaz de construir no espectador a sensação de que o corpo ali se faz presente, embora ele não esteja ali, de fato. Ou seja, a imagem virtual e a real produzem um tipo de atrito, já que é o próprio espectador quem acaba por aplicar na tecnologia um sentido de presença. Assim, o espectador aceita a ambiguidade proposta. 


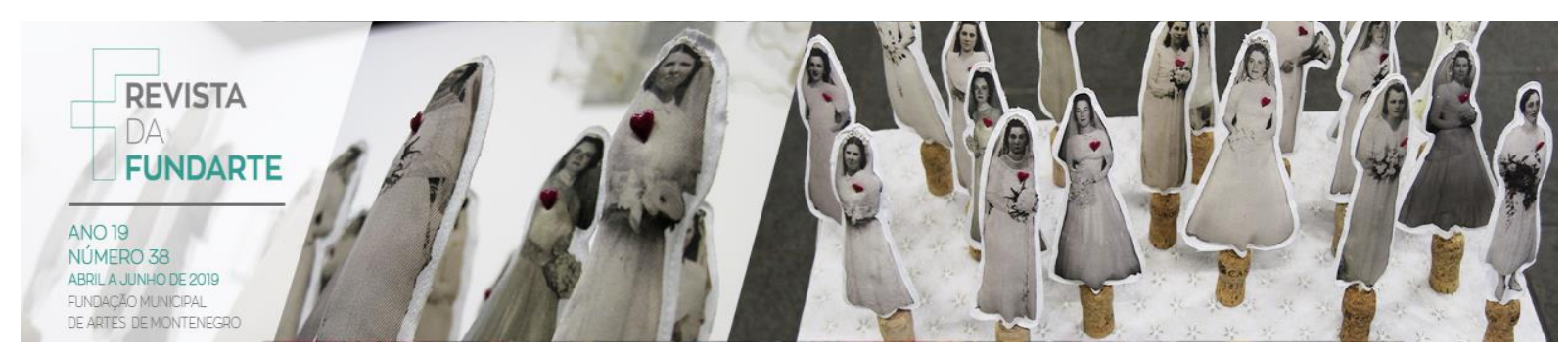

Essa multiplicação de estímulos perceptivos oferece uma possibilidade também dinâmica de abertura para variados caminhos de interpretação e de relação com a obra, como uma ampliação do poder do significado. Ocorre, a partir de então, uma mudança da percepção habitual do espectador. Como explica o autor:

Tudo depende aqui de não compreender imediatamente. Ao contrário a percepção tem de permanecer aberta para esperar, em pontos inteiramente inesperados, ligações, correspondências e explicações que fazem o que se disse antes ser encarado sob uma luz muito diversa. Assim, o significado permanece por princípio suspenso. (LEHMANN, 2007, p.145)[grifo do autor].

Dessa maneira, quem se relaciona com esta arte se contamina permanentemente e indiscriminadamente com os referenciais sugeridos pela vivência pós-moderna. A comunicação espectatorial com o artista e sua obra está constituída dessa relação radicalmente interativa, em que todos são criadores e a proposta de obra aberta, só se concretiza através deste encontro.

Neste sentido, a tarefa do espectador tornou-se mais autônoma, mas por consequência, também mais "trabalhosa". Inúmeras possibilidades são colocadas em suas mãos, e, por isso, o jogo torna-se mais arriscado e difícil. $O$ processo independente de escolhas, implica, ao mesmo tempo, liberdade e responsabilidades. $O$ espectador nesse lugar joga com o perigo, propõe-se a erros e acertos. Não há uma interpretação única ou correta sobre os fatos cênicos. Portanto, é possível que ocorra um processo de frustração, por conta desta perda de referências bases, nas quais seja possível se apoiar. De acordo com Lehmann:

O aparato sensorial humano dificilmente suporta a falta de referência. Privado de seus nexos, ele procura referências próprias, torna-se "ativo", fantasia "descontroladamente", e o que Ihe ocorre então são semelhanças, conexões, correspondências, mesmo as mais remotas. O rastreamento de conexões anda junto com a desamparada concentração da percepção das coisas que se oferecem (talvez elas ainda sussurrem seu segredo). [...] o espectador do novo teatro procura, arrebatado, entendiado ou desesperado, as "correspondências" baudelarianas no "templo do teatro". (LEHMANN, 2007, p.141).

ROCHA, Fernanda Marilia Gomes; MASSA, Clóvis Dias. Navegar o teatro contemporâneo: uma experiência da frustração à autonomia. Revista da FUNDARTE, Montenegro, p.33-45, ano 19, ํㅡ 38, abril/junho de 2019.

Disponível em: http://.seer.fundarte.rs.gov.br/index.php/RevistadaFundarte/index> 28 de junho de 2019. 


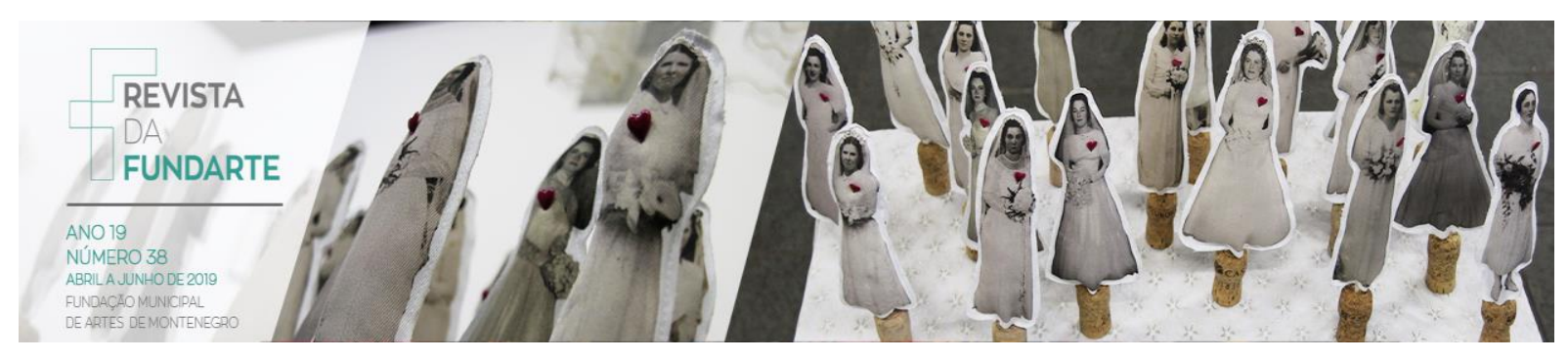

O que este trecho aponta é que o "novo teatro" propõe justamente o contrário daquilo a que estamos acostumados enquanto espectadores. Ou seja, não há mais uma linha narrativa, ou um caminho com pistas claras que possam nos nortear. Porém sofremos com a falta de orientação, ficamos à deriva, sentimo-nos perdidos. Contudo a cena pós-dramática contemporânea nos possibilita a realização teatral da liberdade. Podemos nos entregar a uma outra lógica, própria, como aquela dos sonhos. A estrutura onírica (solta, leve e fragmentada) é o modelo dessa estética que deixa portas semi-abertas (indícios) que podem conduzir o espectador, sem jamais induzi-lo, que podem convidá-lo, sem jamais convocá-lo. A sutil diferença entre impor e propor é o que se torna cada vez mais evidente na experiência do espectador contemporâneo.

Assim, mostra-se possível que a cada nova experiência teatral o espectador iniciante vá habituando-se a essa liberdade e, por conseguinte, se sinta apto a usufruir dela com maior propriedade. O estímulo à constituição de um caminho próprio pode, aos poucos, ir criando o encorajamento necessário para cada espectador assumir seu papel criativo.

Dessa maneira, o que surge a partir daí é um público teatral cada vez mais heterogêneo, que não se aproxima mais por suas semelhanças, mas por suas diferenças. É possível que, após um mesmo espetáculo, cada pessoa da plateia saia com impressões diversas ou até divergentes. Essa possibilidade se mostra radical, na medida em que não se faz mais necessário encontrar e compartilhar de uma mesma interpretação sobre o acontecimento cênico.

Desgranges, em seu artigo Teatralidade tátil: alterações no ato do espectador, explica este fenômeno da relação entre o espectador e a cena pós-dramática:

Em sua relação com a cena pós-dramática, o espectador não encontra orientação de leitura a seguir, que lhe indique pistas para o entendimento da obra e do mundo. De modo que, acompanhando o direcionamento do autor, possa tecer relações racionais, associações lógicas e fechar interpretações. A frustração marca este movimento de leitura na proposta não dramática e, ao mesmo tempo, o estímulo à concepção de percursos próprios, em sua relação com o texto cênico e na relação deste com a vida social. Além do experiência da frustração à autonomia. Revista da FUNDARTE, Montenegro, p.33-45, ano 19, ํㅡ 38, abril/junho de 2019.

Disponível em: http://.seer.fundarte.rs.gov.br/index.php/RevistadaFundarte/index> 28 de junho de 2019. 


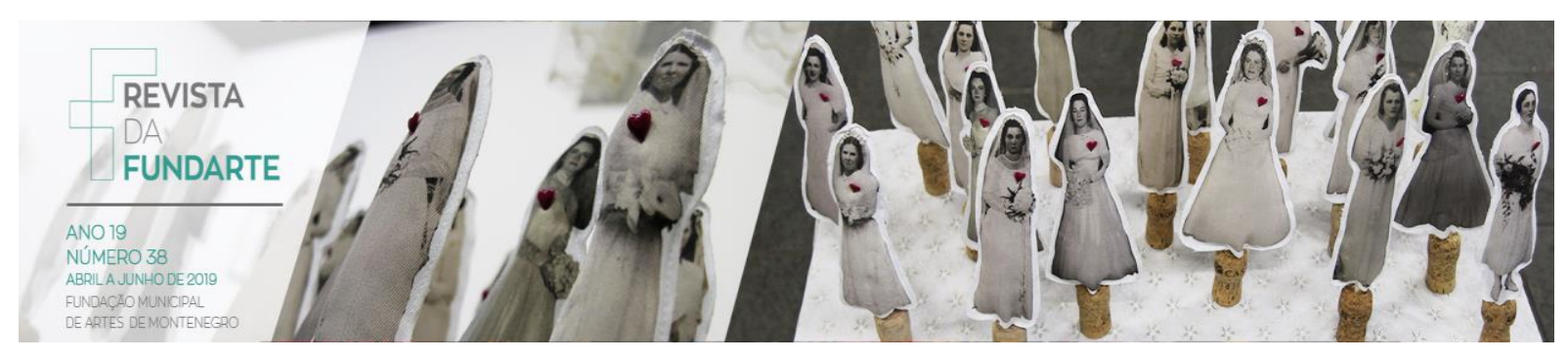

que, conteúdos significativos postos em jogo surgem de maneira surpreendente, inadvertida, pois advindos e inventados pelo próprio leitor durante $o$ ato. $O$ espectador não se pergunta "o que isto quer dizer?", mas sim “o que está acontecendo comigo?"[...]. (DESGRANGES, 2008, p. 19).

De que forma o espectador pode superar essa frustração inicial? É possível que na medida em que o sujeito se aproprie de uma qualidade autônoma e identifique a que se deve seu desejo por teatro, ele consiga superar essa sensação. Cada vez mais, a partir das próprias experiências, é possível que o espectador contemporâneo se sinta apto a percorrer este trajeto, navegando poeticamente pelo oceano de possibilidades do fazer artístico atual e, finalmente, conquistando essa atitude criativa. Ou seja, o desejo de orientação, aos poucos, pode ir dando lugar ao desejo pela autonomia criadora. Pode-se afirmar que ela não é simplesmente adquirida, mas conquistada à medida que o sujeito se põe em contato com o universo teatral, se familiarizando com as convenções dessa arte. Portanto há um olhar muito mais próprio de relação com a cena, a qual lança o enfoque principal na experiência pessoal de cada espectador. $O$ espectador pode olhar para si e questionar suas próprias reações e sensações. Nesse sentido, a cena atual cria acontecimentos em que cabe ao público uma esfera de decisão, cabe a ele fazer suas escolhas e elaborar um sentido próprio e, portanto, singular. Provoca, dessa forma, um estado de alerta que se difere de um estado de relaxamento puramente contemplativo. Assim, o teatro hoje ultrapassa as barreiras da ilusão e, por conseguinte, os espectadores podem identificar aí a porta de abertura para o prazer da liberdade.

Ressalto, a fim de esclarecimento, que todas as obras feitas em nossa atualidade são consideradas contemporâneas. Nesse sentido, mesmo que não se denominem como "pós-dramáticas", estão contagiadas pelos novos processos de criação e recepção, ou ainda, pelas características de nossa atualidade, tanto de dentro como de fora da cena. Além disso, é importante lembrar que esses avanços em relação ao trabalho do espectador vêm acontecendo desde o Teatro Moderno, quando 


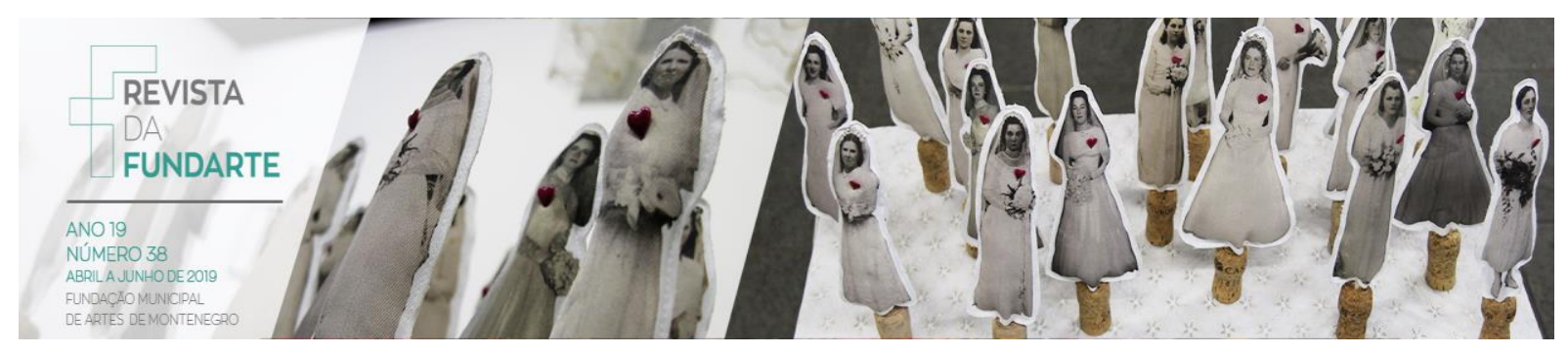

Ihe foi solicitado uma atitude ativa frente à encenação, especialmente a partir das propostas cênicas de Meyerhold, Piscator e Brecht:

\begin{abstract}
Se, até então, o espectador podia fruir a experiência teatral inadvertidamente, sem consciência de seu papel no evento, a partir da modernidade, e o teatro épico brechtiano intensifica esse procedimento, se opera a tomada de consciência de sua atividade ante o diálogo que a cena Ihe propõe. A atuação produtiva do espectador estaria assim afirmada, caberia a ele, ao dialogar com os signos cênicos e interpretá-los, empreender um ato necessária e explicitamente autoral (DESGRANGES, 2010, p.44).
\end{abstract}

Denis Guénoun, em $O$ teatro é necessário?, aponta para a hipótese de que nos dias atuais, o desejo pelo teatro está ligado à necessidade de jogar. $O$ jogo traz em si a sensação do efêmero e a capacidade de reinventar-se. Ele desvincula o teatro de um papel ou uma trama, necessariamente ou a priori. Agora ele se justifica por ele mesmo. O teatro abraça o jogo e com ele a possibilidade de se mostrar tal como ele é: teatral. Ou seja, não é mais preciso representar "como se tudo fosse de verdade", não é mais necessário "esconder" aquilo que compõe a essência do fazer teatral, aquilo que põe em evidência sua principal característica: a de ser uma arte viva. Nesse momento, o teatro configura-se, mais do que nunca, como uma arte jogadora, movida pela ação (à mostra), através de presenças concretas. Isso não quer dizer que não haja ficção, nem personagens, mas sim que não fazemos mais teatro tão somente para representá-los. E que não vamos mais ao teatro somente para vê-los. Nesse caso, quando vamos assistir a um espetáculo, estamos ansiosos para ver o como, ou seja, o "tornar-se-teatro" de uma ação, de uma ideia, de um universo imaginário. Não somente a ação, a história, ou o papel, mas a encenação em si. A necessidade da ilusão deu lugar ao desejo de se ver apresentar, em outras palavras, a verdade do jogo. Como acabamos de ver, é a exigência dessa forma específica de jogar que impulsiona os espectadores hoje em dia. Especificidade feita de verdade, poesia e presença íntegra de seus jogadores. Mas mais do que isso, feita, sobretudo, de entrega. abril/junho de 2019.

Disponível em: http://.seer.fundarte.rs.gov.br/index.php/RevistadaFundarte/index> 28 de junho de 2019. 


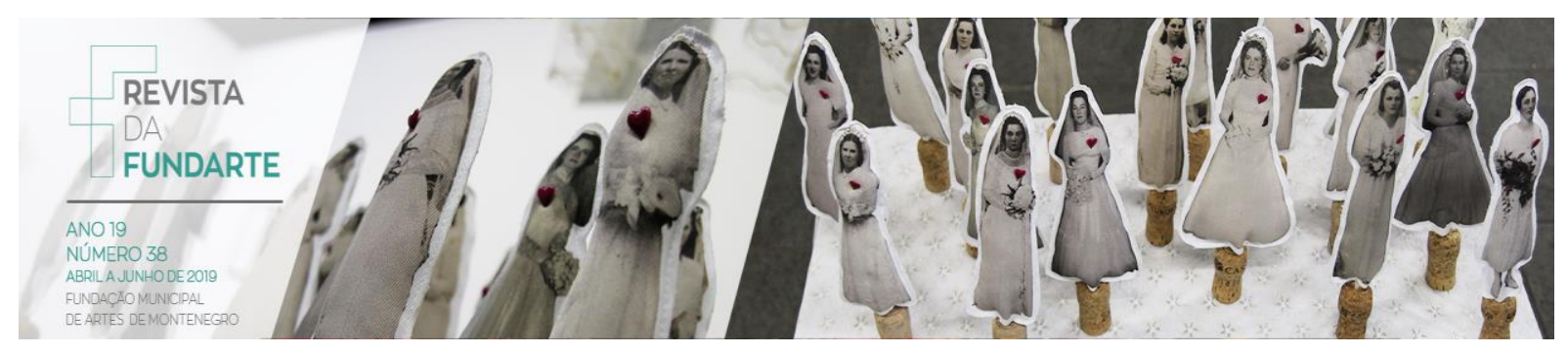

Portanto, os espectadores de teatro hoje possivelmente seriam aqueles que necessitam, essencialmente, compartilhar desse jogo, livres de respostas prontas e plenos de vontade criadora. Porque dentro deles um desejo os anima: o de que diante dessa entrega jogadora do ator, eles possam entregar-se também.

\section{Referências:}

DE MARINIS, Marco. Comprender el teatro: Lineamentos de una nueva teatrología. Buenos Aires: Galerna, 1997.

Aires: Galerna, 2005.

. En busca del actor y del espectador: Comprender el teatro II. Buenos

DESGRANGES, Flávio. Teatralidade tátil: alterações no ato do espectador. Revista Sala Preta, 2008, n 8, ECA-USP, São Paulo.

A pedagogia do espectador. São Paulo: Hucitec, 2010.

FÉRAL, Josette. Teatro, Teoria y Practica: Mas Alla de Las Fronteras. Buenos Aires: Galerna, 2004.

GUÉNOUN, Denis. O teatro é necessário? São Paulo: Perspectiva, 2004.

LEHMANN, Hans-Thyes. Teatro pós-dramático. São Paulo: Cosac \& Naify, 2007.

Teatro Pós-Dramático e Teatro Político. tradução de Raquel Imanishi, artigo in Revista Sala Preta número 3, Departamento de Artes Cênicas/USP, São Paulo: 2003.

MORIN, Edgar. Introdução ao Pensamento Complexo. Lisboa: Ed. Instituto Piaget, 2003.

ROCHA, Fernanda Marília. O Hábito Habitável: a experiência de ser espectador com alunos de uma escola pública de Porto Alegre. Dissertação (Mestrado em Artes Cênicas), Programa de Pós-Graduação em Artes Cênicas, Universidade Federal do Rio Grande do Sul, Porto Alegre, 2012.

UBERSFELD, Anne. Para ler o teatro. São Paulo: Perspectiva, 2005. 